\title{
4K/8K, UHD Premium Certification, HLG, PQ, WCG, HEVC HDR10
}

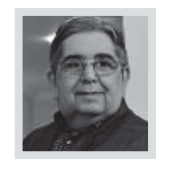

Moderator: Celso Eduardo Araujo

DIGITAL CINEMA DIRECTOR at SET / LINK Multiserviços Eletroeletrônicos

ULTRA HD PREMIUM Certification

Speaker: Celso Eduardo Araujo

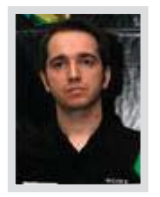

HLG - Hybrid Log-Gamma \& PQ - Perceptual Quantizer

Speaker: Erick Soares

Engenheiro de Suporte a Vendas - Marketing - Professional Solutions Brazil - SONY

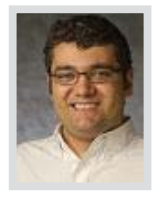

WCG - Wide Color Gamut

Speaker: Eliesio Silva Junior

Video Account Manager - Tektronix

HEVC Main 10 - HDR10:

Speaker: Gustavo Marra

Vice President, Solutions \& Business Development - ATEME

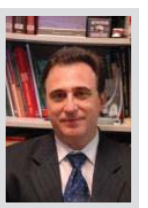

Pesquisa em UHD: Muito Além da Alta Definição

Speaker: MARCELO KNORICH ZUFFO

Professor Titular da Escola Politécnica / Universidade de São Paulo - USP 


\section{K/8K, UHD PREMIUM CERTIFICATION, HLG, PQ, WCG, HEVC HDR10}

Moderator: Celso Eduardo Araujo

DIGITAL CINEMA DIRECTOR at SET / LINK Multiserviços Eletroeletrônicos

- ULTRA HD PREMIUM Certification

Speaker: Celso Eduardo Araujo

Diretor de Cinema Digital da SET / Link Multiserviços Eletroeletrônicos

ULTRA HD PREMIUM Certification: Certification for new UHD-1 and UHD-2 television sets with the specifications and performance metrics deliberated by The UHD ALLIANCE - UHDA which is a global consortium with more than 35 companies;

- HLG - Hybrid Log-Gamma \& PQ - Perceptual Quantizer Speaker: Erick Soares

Engineer at SONY

HLG - Hybrid Log-Gamma: Reflecting the latitude High Dynamic Range (HDR), which will make possible the transmission of a single signal compatible with HDR and non-HDR televisions. The principle of operation occurs by assigning the decoding of the luminance signal into two parts, a lower half and another upper high-dynamic range signal, with the bottom part using a standard gamma curve, while the upper uses a logarithmic curve. Defined by the standard ARIB STD-B67 (development of the BBC and NHK); PQ - Perceptual Quantizer: A new quantization set curve from the luminance changes in human visual perception, with the brightness levels of 0 to $10,000 \mathrm{~cd} / \mathrm{m} 2$, adopting 10 bit or 12 bit encoding. This new resulting curve, PQ - Perceptual Quantizer replaces the Gamma in the image coding in new televisions. Defined by SMPTE ST2084 OETF/EOTF;

- WCG - Wide Color Gamut Speaker: Eliesio Silva Junior Video Account Manager - Tektronix

WCG - Wide Color Gamut: Paleta maior de cores do que as suportadas pelos atuais Televisores com espaços de cor BT.709 e BT.601 e que só capturam uma percentagem relativamente pequena $(\sim 33,5 \%)$ da visão humana, e, agora com o novo padrão WCG - Wide Color Gamut com espaços de cores mais amplos, como o P3D65 (Projetores) e o BT.2020 (Televisores/Monitores) e que podem representar uma percentagem muito maior da Cromaticidade visível ( $45,5 \%$ e $\sim 63,3 \%$, respectivamente). Definida pela norma ITU-R BT.2020-2;

- HEVC Main 10 - HDR10: Speaker: Gustavo Marra

Vice President, Solutions \& Business Development - ATEME

WCG - Wide Color Gamut: Larger color palette than supported by current TVs with BT.709 and BT.601 color spaces and which only capture a relatively small percentage $(\sim 33.5 \%)$ of human vision, and now with the new standard WCG - Wide color Gamut with larger color spaces, such as P3D65 (Projectors) and BT.2020 (TVs/monitors), which may represent a much higher percentage of visible chromaticity ( $\sim 5.5 \%$ and $\sim 63.3 \%$, respectively). Defined by ITU-R BT.2020-2 standard; 


\title{
- Pesquisa em UHD: Muito Além da Alta Definição
}

\author{
Speaker: MARCELO KNORICH ZUFFO
}

Professor Titular da Escola Politécnica / Universidade de São Paulo - USP

Comparação fotométrica, colorimétrica e frequência. Desafios para imersão: Quando e Como ela ocorre.

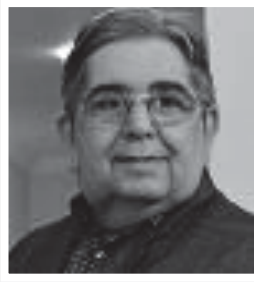

\section{CELSO EDUARDO ARAUJO}

DIGITAL CINEMA DIRECTOR - SET

Joined TV Globo in 1973 as a Maintenance Technician at the Globo Engineering Center in Rio de Janeiro. He worked for around 12 years in Maintenance, during which time had the opportunity for development in several sectors, such as cameras, lenses, video-tape, audio, switches, routers. He also managed systems and teams in addition to managing Production Operations as well as sporting events, concerts and show.

Since the 80 s he has been involved with the adaptation and requirements for producing TV drama, with acquisition in $35 \mathrm{~mm}$ film, emulsion manufacturers and processing laboratories, as well as finalization and transfer companies.

From 1998 onwards, he began studying and developing HDTV for application in TV drama productions and digital cinema.

Project leader and integration of the SHOPTIME cable and satellite channel in the transition to digital.

From 2003 until today, he has been involved in the research and development of the HD video capture process and its impacts on the areas of Scenography, Costumes, Characterization and Makeup, Lighting and Post-Production. Implementation of the capture process and post-production of HD video in the LOGARITHMIC format using large-sensor cameras for the "CAPITU" and "MAYSA" series, as well as the movie "OS NORMAIS II".

Founding associate of the Brazilian Society of Television Engineering, SET, and since 2005 Director for Digital Cinema.

He graduated from the CEFET in Campos in the Mechanics of Machinery and in Electronics Operations Engineering from the Santa Úrsula University and an MBA in Business Management from the IAG PUC-Rio

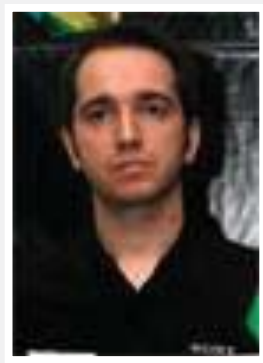

\section{ERICK SOARES}

Sales Support Engineer, marketing - SONY

Sales Support Engineer for more than 15 years at Sony, specialist in new technologies and products on the broadcast market, educated at F.E.I (School of Industrial Engineering - S.B.C./SP) with a graduate degree from F.I.A. (Institute of Administration Foundation USP). Accompanied the development of new products, serving as the intermediary between Brazilian customers and the engineers in Japan, while also participating in several domestic (SET, Broadcast \& Cable, Anima Mundi, SSPI) and international events

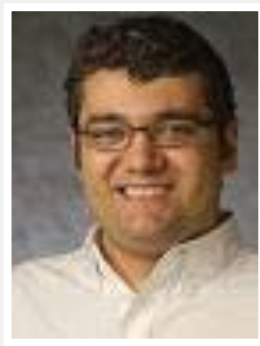

\section{ELIESIO SILVA JR}

Video Account Manager - Tektronix

Eliésio Silva Júnior graduated as an Electronics Technician and Telecommunications Technician; he also has an undergraduate degree in Electronics, a graduate degree in Satellite Transmission and a graduate degree in Logistics, an MBA in Enterprise Management and an MBA in Digital TV. He was a substitute member on the Regional Council of the CREA RJ, between 2009 and 2010; worked at TV Record from 1993 to 1995; at TV Globo between 1997 and 1999; Globosat, between 1994 and 2010 and has been at Tektronix since 2010. He is currently Tektronix Distribution and Accounts Manager for Latin America.

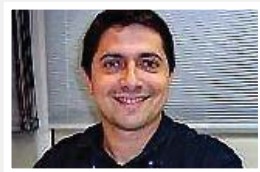

\section{GUSTAVO MARRA}

Vice President, Solutions \& Business Development - ATEME 


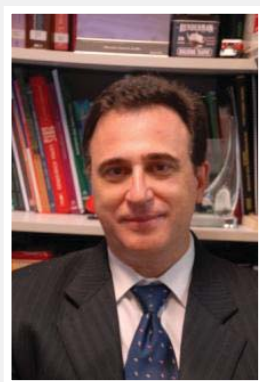

\section{MARCELO KNÖRICH ZUFFO}

Professor Titular da Escola Politécnica da Universidade de São Paulo (USP)

An Electrical Engineer from the Polytechnic School of the University of São Paulo (1989), with a Master's in Electrical Engineering (1993), a Doctorate in Electrical Engineering (1997), a lecturer specializing in Interactive Electronic Media and Titular Professor (2006) of the Department of Electronic Systems Engineering of the Polytechnic School of the University of São Paulo. He has been involved with the Integrable Systems Laboratory (LSI), coordinating research and development in the field of Interactive Electronic Media, with the focus on the following topics: interactive media engineering, digital healthcare, high-performance computing, virtual reality, computer graphics and display. In 2001, he developed the first total immersive virtual reality system in Brazil, called Digital Cave (Caverna Digital). Since 2011, he has been coordinating the Interdisciplinary Center in Interactive Technologies at the University of São Paulo (USP). 